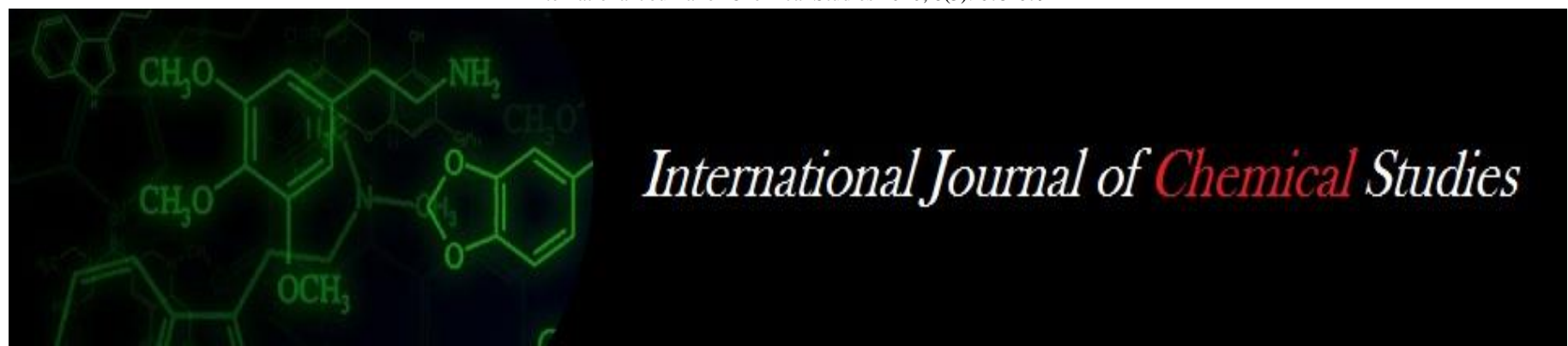

P-ISSN: 2349-8528

E-ISSN: 2321-4902

www.chemijournal.com

IJCS 2020; 8(3): 675-679

(C) 2020 IJCS

Received: 25-03-2020

Accepted: 26-04-2020

Pinky Yadav

Ph D Scholar, Department of

Agronomy, MPUA\&T, Udaipur,

Rajasthan, India

SS Yadav

Professor \& Head, Department of Agronomy, SKNAU, Jobner,

Rajasthan, India

Kamal Garg

Ph D Scholar, Division of

Agronomy, IARI New Delhi,

India

Sonal Athnere

Ph D Scholar, Department of

Agronomy, MPUA\&T, Udaipur,

Rajasthan, India

Seema Yadav

Ph D Scholar, Department of

Agronomy, SKNAU, Jobner,

Rajasthan, India
Corresponding Author:

Pinky Yadav

Ph D Scholar, Department of

Agronomy, MPUA\&T, Udaipur,

Rajasthan, India

\section{Effect of sulphur and zinc fertilization on productivity and economics of sesame (Sesamum indicum L.) in semi-arid conditions of Rajasthan}

\author{
Pinky Yadav, SS Yadav, Kamal Garg, Sonal Athnere and Seema Yadav
}

DOI: https://doi.org/10.22271/chemi.2020.v8.i3h.9285

\begin{abstract}
A field experiment was conducted at Agronomy farm, S.K.N. College of Agriculture, Jobner, Jaipur (Rajasthan) during kharif season of 2018 to study the effect of sulphur and zinc fertilization on productivity and economics of sesame. The experiment comprising of four levels each of sulphur $(0,15$, 30 and $45 \mathrm{~kg} / \mathrm{ha})$ and zinc $(0,10,20$ and $30 \mathrm{~kg}$ zinc sulphate/ha), thereby making 16 treatment combinations was laid out in factorial randomized block design and replicated thrice. Results showed that progressive increase in level of sulphur up to $30 \mathrm{~kg} / \mathrm{ha}$ significantly increased the most of the yield attributing characters of sesame viz., number of capsules/plant, number of seeds/capsule and test weight over preceding levels. It also recorded significantly higher seed yield $(712 \mathrm{~kg} / \mathrm{ha})$ of sesame over control and $15 \mathrm{~kg} / \mathrm{ha}$ and found at par with $45 \mathrm{~kg} / \mathrm{ha}$. Result further showed that every increase in level of zinc sulphate up to $20 \mathrm{~kg} / \mathrm{ha}$ by and large significantly improved most of the yield determining characters of sesame over lower levels. It also recorded significantly higher seed yield $(725 \mathrm{~kg} / \mathrm{ha})$ over control and 10 $\mathrm{kg} / \mathrm{ha}$ and found at par with $30 \mathrm{~kg} / \mathrm{ha}$. The results further showed that according to economic and marginal analysis, progressive increase in level of sulphur upto $30 \mathrm{~kg} \mathrm{~S}^{-1}$ and zinc $20 \mathrm{~kg} \mathrm{Zn} \mathrm{ha}{ }^{-1}$ seemed highly practical due to higher net returns, benefit cost ratio (BCR) and optimum dose of sulphur and zinc for sesame crop were computed as $39.24 \mathrm{~kg} \mathrm{~S} \mathrm{ha}^{-1}$ and $26.30 \mathrm{~kg} \mathrm{Zn} \mathrm{ha}^{-1}$, respectively.
\end{abstract}

Keywords: B:C ratio, economics, net returns, sulphur, yield and zinc

\section{Introduction}

Sesame (Sesamum indicum L.) is an ancient oilseed crop of the world. It is an important edible oilseed crop next to groundnut and rapeseed-mustard. In old literature, the sesame seed was referred to as the" queen of oilseed", and sesame oil is among the first oils know and consumed by man (Prasad, 2017) ${ }^{[9]}$. Sesame is grown on more than 8.0 million hectares with production of 5.0 million tonnes and productivity of $565 \mathrm{~kg} / \mathrm{ha}$ (Anonymous, 2016-17) ${ }^{[2]}$. India is the largest producer of sesame in the world. It is cultivated on 20 lakh hectares in country with total production of 8.11 lakh tonnes. The average productivity of the crop is $430.5 \mathrm{~kg} / \mathrm{ha}$ (Anonymous, 2016-17) ${ }^{[2]}$. It is extensively cultivated in the states of Gujarat, West Bengal, Tamil Nadu, Maharashtra, Karnataka, Rajasthan and Madhya Pradesh. Sesame has the highest oil content of $42-50 \%$ along with $25 \%$ protein compare to other oilseed crops. The sesame oil contains 16-18\% carbohydrate and 42\% essential linoleic acid (Miah et al., $2015)^{[6]}$, and the high grades of sesame oil are used for cooking, margarine manufacturing and in pharmaceutical industries (El Naim et al., 2012) ${ }^{[5]}$. Sesame cake contains $6.0-6.2 \%$ N, 2.0$2.2 \% \mathrm{P}_{2} \mathrm{O}_{5}$ and $1.0-1.2 \%$ of $\mathrm{K}_{2} \mathrm{O}$ and can be used as manure. Sulphur an essential plant nutrient can play a key role in augmenting the production and productivity of oilseeds in the country as it has a significant influence on quality and development of oil seeds and best known for its role in the synthesis of proteins, oils and vitamins. Available sulphur in soil is frequently lower than 5-10 ppm in light textured soil of Rajasthan. Sulphur deficiency is becoming more critical with each passing year which is severely restricting crop yield, produce quality and nutrient use efficiency. Sulphur, therefore, is now very much a part of balanced fertilization because in $\mathrm{S}$ deficient areas, applying $\mathrm{N}, \mathrm{P}$ and $\mathrm{K}$ only, even at recommended rates cannot produce high yields unless $\mathrm{S}$ is also applied. Sulphur research work done in different parts of the country indicates that application of sulphur is highly profitable and seems to be essential for boosting the crop production. 
Zinc being one of the essential micronutrients, plays significant role in various enzymatic and physiological activities of the plant body. It is also essential component of synthetic and natural organic complexes in plants. There are estimates that more than $30 \%$ of agricultural soils at global level are low in available Zn leading to deficiency in crops cultivated on these soils (Alloway 2008) ${ }^{[1]}$. Therefore, Zn malnutrition has become a major health concern among the resource poor people (Singh, 2011) ${ }^{[10]}$. In India, $\mathrm{Zn}$ is one of the multi-nutrient deficiencies causing poor crop yields. Zinc deficiency in Indian soils is expected to increase from $42 \%$ in 1970 to $63 \%$ by 2025 due to continuous depletion of soil fertility (Singh 2011) ${ }^{[10]}$. Under zinc deficient conditions, flowering and fruit development is reduced, and growth period is prolonged resulting in delayed maturity, leading to lower yield, poor quality and suboptimal nutrient use efficiency. Hence, in the present study, different levels of sulphur and zinc are evaluated under semi-arid conditions of Rajasthan on productivity and economics of Sesame (Sesamum indicum L.).

\section{Materials and method}

The experiment was conducted during kharif season 2018 at Agronomy farm, S.K.N. College of Agriculture, Jobner, Jaipur (Rajasthan). The soil of the experimental field was loamy-sand in texture, alkaline in reaction ( $\mathrm{PH} \mathrm{8.2),} \mathrm{poor} \mathrm{in}$ organic carbon $(0.19 \%)$, low in available nitrogen (120.3 $\mathrm{kg} / \mathrm{ha}$ ) and medium in phosphorus (17.23 kg/ha) and potassium $(141.08 \mathrm{~kg} / \mathrm{ha})$. The experiment consisting of 4 levels of each sulphur and zinc there by making sixteen treatment combination that were laid out in factorial randomized block design and replicated three times. The plot size was $4.0 \mathrm{~m} \times 3.0 \mathrm{~m}$. Sesame crop was sown on $8^{\text {th }}$ July 2018. Sulphur and Zinc was applied through gypsum of agriculture grade (70-80 \% pure) and Zinc sulphate (heptahydrate) respectively before sowing as per treatment and was incorporated well into the soil. A uniform application $30 \mathrm{~kg} \mathrm{~N}$ and $25 \mathrm{Kg}_{2} \mathrm{O}_{5}$ /ha was applied to all the plot through urea and DAP respectively. Thinning, hoeing and weeding were done after 22 days of sowing to maintain recommended spacing, proper aeration and weed free field. Sesame crop was harvested on $4^{\text {th }}$ October, 2018 after leaving two border rows on each side of plot along the length on both sides, a net area of $3.0 \mathrm{~m} \times 1.8 \mathrm{~m}$ was harvested separately from each plot to assess the grain yields from net plot area. A small seed sample was taken from the produce of each of the plot harvested and 1000-seeds were counted and weighed in grams and recorded as test weight. In each plot, bundles were tied and tagged properly and transported on threshing floor for proper sun drying. The total biomass harvested from each net plot was threshed, cleaned and dried. The clean grain obtained from individual plot was weighed separately and weight recorded as grain yield ( $\mathrm{kg} / \mathrm{plot})$. To find out the most profitable treatment, economics of different treatments were worked out in terms of net returns ( $₹ / \mathrm{ha}$ ) on the basis of the prevailing market rate. The total cost of cultivation was deducted from the gross realization to work out the net income for each treatment combinations and was recorded accordingly. Benefit cost ratio for each treatment was calculated to ascertain economic viability of the treatment.

$$
\text { Benefit cost ratio }(\mathrm{BCR})=\frac{\text { Net Returns }}{\text { Cost of cultivation }}
$$

Optimum level of sulphur and zinc was worked out with the help of quadratic equation by using the least square technique.

$$
\mathrm{Y}=\mathrm{b}_{0}+\mathrm{b}_{1} \mathrm{X}+\mathrm{b}_{2} \mathrm{X}^{2}
$$

Where

$\mathrm{Y}=$ Expected grain yield $(\mathrm{kg} / \mathrm{ha}) \mathrm{X}=$ Level of sulphur/zinc $(\mathrm{kg} / \mathrm{ha}) \mathrm{b}_{0}=$ Constant

$b_{1}$ and $b_{2}=$ Regression coefficients

After fitting the response curve, optimum level of sulphur and zinc were worked out by the following formula:

Xopts $=\frac{\mathrm{Q} / \mathrm{P}-\mathrm{b}_{1}}{2 \mathrm{~b}_{2}}$

Where,

Xopt = optimum level of sulphur $(\mathrm{kg} / \mathrm{ha})$ and zinc $(\mathrm{kg} / \mathrm{ha})$

$\mathrm{P}=$ price per $\mathrm{kg}$ seed yield (₹)

$\mathrm{Q}=$ Cost of sulphur and zinc per $\mathrm{kg}(₹)$

$b_{1}$ and $b_{2}=$ Coefficients of response equation $(\mathrm{kg} / \mathrm{ha})$

\section{Result and Discussion \\ Yield attributes and grain yield}

Increasing levels of sulphur fertilization up to $30 \mathrm{~kg} / \mathrm{ha}$ significantly improvement in the number of capsules/plant, seed/capsule and test weight in sesame (Table 1). All these yield attributes registered maximum values at $45 \mathrm{~kg} \mathrm{~S} / \mathrm{ha}$. The marked improvement in capsules/plant and test weight by applying sulphur could be ascribed to overall improvement in vigour and crop growth as a consequence balanced nutritional environment as discussed above. Supply of sulphur in adequate amount also helps in the development of floral primordial i.e. reproductive parts, which results in the development of capsules and seeds in plants. Similar findings have also been reported earlier by Tripathi and Rajput (2007) ${ }^{[14]}$, Yadav et al. (2008) ${ }^{[16]}$ and Shinde et al. (2011) ${ }^{[12]}$ in sesame. Progressive increase in levels of sulphur up to 30 $\mathrm{kg} / \mathrm{ha}$ also produced significantly more seed yield of sesame (Table 1). The extent of increase in seed yield of sesame was 10.4 and 37.1 per cent over $15 \mathrm{~kg} / \mathrm{ha}$ and control, respectively. The significant increase in seed yield was largely a function of improved growth and the consequent increase in various yield attributes due to $S$ fertilization in addition to its multiple roles in metabolism as an essential constituent of amino acids and also improvement in vegetative structures and assimilates thereby maintaining balanced source-sink (Shah et al. 2013) [11]. Similarly, yield attributing characters of sesame were significantly improved by zinc fertilization. Application of zinc sulphate at $20 \mathrm{~kg} / \mathrm{ha}$ recorded significantly higher yield contributing characters viz. number of capsules/plant, number of seed/capsule, test weight, as well as seed yield of sesame were significantly increased due to application of zinc $20 \mathrm{~kg}$ $\mathrm{ZnSO}_{4} / \mathrm{ha}$ over preceding levels ( 0 and $10 \mathrm{~kg} / \mathrm{ha}$ ). Further increase in level of zinc sulphate to $30 \mathrm{~kg} / \mathrm{ha}$, though, attained the highest values of all the yield determining characters, but variation was not of statistically significance from $20 \mathrm{~kg}$ $\mathrm{ZnSO}_{4} /$ ha (Table 1). It can be assigned due to the overall improvement in vigour and crop growth as reflected in plant height and dry matter production. The favorable effect of $\mathrm{Zn}$ fertilization on yield attributes might be due to the fact that zinc is well known for its role as 'enzyme activation' biosynthesis of auxin hormone in various metabolic processes. The positive effect of zinc on seed yield might 
have been due to its requirement in carbohydrate synthesis, the pronounced role in photosynthesis and cell elongation. These results also corroborate with Singaravel et al. (2001) ${ }^{[13]}$ in sesame.

Interaction: Seed yield of sesame was also influenced significantly due to combine effect of sulphur and zinc fertilization (Table 2). Application of $30 \mathrm{~kg} \mathrm{~S} / \mathrm{ha}$ along with zinc sulphate at $20 \mathrm{~kg} / \mathrm{ha}\left(\mathrm{S}_{30} \mathrm{Zn}_{20}\right)$ was the most effective treatment combination. It produced the seed yield of 802 $\mathrm{kg} / \mathrm{ha}$ which was higher by $337 \mathrm{~kg} / \mathrm{ha}$ in comparison to $\mathrm{S}_{0} \mathrm{Zn}_{0}$, wherein the minimum seed yield of $465 \mathrm{~kg} / \mathrm{ha}$ was obtained. Being at par with $\mathrm{S}_{30} \mathrm{Zn}_{20}, \mathrm{~S}_{45} \mathrm{Zn}_{30}$ produced the highest seed yield $(860 \mathrm{~kg} / \mathrm{ha})$ and was closely followed by $\mathrm{S}_{45} \mathrm{Zn}_{20}$ and $\mathrm{S}_{30} \mathrm{Zn}_{30}$ treatment combinations.

\section{Net Return}

Data pertaining to the effect of varying levels of sulphur fertilization on net returns in sesame have been presented in (Table 1). Results showed that every increase in level of sulphur from control to $30 \mathrm{~kg} / \mathrm{ha}$ fetched significantly higher net returns over control respectively. Further increase in its level to $45 \mathrm{~kg} / \mathrm{ha}$, though, provided the highest net returns of $₹ 42350 /$ ha, yet the difference between these two levels was not of statistical significance. This level of $\mathrm{S}$ fertilization provided the additional net returns of ₹ 6412 and 17752/ha over $15 \mathrm{~kg} \mathrm{~S} / \mathrm{ha}$ and control, respectively. It is further apparent from the data (Table 1) that increasing levels of zinc sulphate fertilization fetched significantly higher net returns in sesame over preceding levels up to $20 \mathrm{~kg} / \mathrm{ha}$. Results showed that application of zinc sulphate at 20 and $30 \mathrm{~kg} / \mathrm{ha}$ provided the net returns of $₹ 42153$ and $42838 /$ ha, thereby indicating a significant increase of 18.0 and 20.0 per cent over $10 \mathrm{~kg} / \mathrm{ha}$ and 77.5 and 80.4 per cent over control, respectively. However, these two levels of zinc sulphate remained at par with each other in improving net returns. As net return is calculated by multiplying the seed yield and their sale prices and subtracting the total cost of cultivation including treatment cost. Thus, higher net return could be primarily due to higher seed and stalk yields with comparatively lesser additional cost of input compared to additional yield under this treatment. Similar findings were also reported by Bhosale (2011) ${ }^{[3]}$ and Dash et al. (2013) ${ }^{[4]}$ in sesame.

Interaction: Interaction effect of varying levels of sulphur and zinc fertilization on net returns in sesame was also noted to be influenced significantly (Table 2). Application of sulphur at $30 \mathrm{~kg} / \mathrm{ha}$ combined with zinc sulphate at $20 \mathrm{~kg} / \mathrm{ha}$ $\left(\mathrm{S}_{30} \mathrm{Zn}_{20}\right)$ was found as the most remunerative treatment combination in obtaining net returns. It was followed in the order of $\mathrm{S}_{45} \mathrm{Zn}_{20}, \quad \mathrm{~S}_{45} \mathrm{Zn}_{30}$ and $\mathrm{S}_{45} \mathrm{Zn}_{20}$ combinations. Remaining at par among themselves, these four combinations fetched additional net returns of ₹ 27110, 26490, 30720 and $31160 /$ ha in comparison to $\mathrm{S}_{0} \mathrm{Zn}_{0}$, wherein, the lowest net return of ₹ 21860 were obtained.

\section{B:C ratio}

A perusal of the data presented in (Table 1) revealed that different levels of sulphur differed significantly in their B:C ratio values. Application of sulphur at 30 and $45 \mathrm{~kg} / \mathrm{ha}$ attained the $\mathrm{B}: \mathrm{C}$ ratio values of 1.83 and 1.84 representing a significant increase 15.0 and 15.7 per cent over $15 \mathrm{~kg}$ S/ha and 64.8 and 65.7 per cent over control, respectively. However, they were found statistically at par with each other. Results presented in (Table 1) also indicated that successive addition in level in zinc sulphate resulted in significantly higher B:C ratio values up to $20 \mathrm{~kg} / \mathrm{ha}$ over lower levels. The highest $\mathrm{B}: \mathrm{C}$ ratio (1.82) was recorded at this level of zinc fertilization indicating an increase of 11.0 and 55.6 per cent over $10 \mathrm{~kg} / \mathrm{ha}$ and control, respectively. Application of $30 \mathrm{~kg}$ zinc sulphate/ha witnessed $\mathrm{B}: \mathrm{C}$ ratio of 1.74 and found at par with $20 \mathrm{~kg} / \mathrm{ha}$ because above this level increase in seed yield was slow as compare to the cost of the higher treatments. So, $\mathrm{B}: \mathrm{C}$ ratio also decreases.

Interaction: It is clear from the data (Table 2) that $\mathrm{B}$ : $\mathrm{C}$ ratio in sesame was affected significantly due to combined effect the sulphur and zinc fertilization. The highest B: $\mathrm{C}$ ratio (2.27) was observed when $30 \mathrm{~kg} \mathrm{~S} / \mathrm{ha}$ was integrated with application of zinc sulphate at $30 \mathrm{~kg} / \mathrm{ha}\left(\mathrm{S}_{30} \mathrm{Zn}_{30}\right)$. It was followed by $\mathrm{S}_{45} Z_{30}, \mathrm{~S}_{30} \mathrm{Zn}_{20}$ and $\mathrm{S}_{45} \mathrm{Zn}_{20}$ combinations. These combinations increased the B: $\mathrm{C}$ ratio by 108.3 , 94, 5, 93.6 and 79.8 per cent over $\mathrm{S}_{0} \mathrm{Zn}_{0}$ and thus found equally effective.

\section{Optimum dose}

To describe the relationship between seed yield and applied sulphur and zinc, multiple regression studies were undertaken. Response of seed yield to varying levels of sulphur and zinc was worked out and found to be the quadratic (Table 3). This relationship of type $\left(Y=b_{0}+b_{1} X+b_{2} X^{2}\right)$ describing seed yield (Y) as a function of main effects of sulphur and zinc sulphate levels showed a curvilinear trend expressed as a second-degree polynomial in $\mathrm{S}$ and $\mathrm{Zn}$. The predicted yield work out from this quadric function showed very high closeness to the observed data as evidenced from very high value of $R^{2}$. The regression coefficient of second order function was fitted for one season. Mean data were found to be highly significant. The perusal of data (Table 3) showed that application of $39.24 \mathrm{~kg} / \mathrm{ha}$ was found the optimum dose of sulphur with seed yield of $725.57 \mathrm{~kg} / \mathrm{ha}$ and response of $5.24 \mathrm{~kg} / \mathrm{kg} \mathrm{S}$. The available status of S significantly increased with sulphur application. This increase might be due to amelioration effect of sulphur and improved physicochemical properties of soil. The higher amount of available sulphur coated be attributed to a greater mineralization of organic sulphur and release of $\mathrm{SO}^{2-}$ ions on its gradual oxidation (Pathan and Nag, 2008) ${ }^{[8]}$. Similar findings were also reported by Vaghani et al. (2010) ${ }^{[15]}$ and Najar et al. (2011) [7]. Similarly, further study of the data presented in (Table 3) indicated that optimum dose of zinc sulphate was $26.30 \mathrm{~kg} / \mathrm{ha}$, corresponding with seed yield of $747.29 \mathrm{~kg} / \mathrm{ha}$ and response of $9.8 \mathrm{~kg} / \mathrm{kg}$ zinc sulphate.

Table 1: Effect of sulphur and zinc fertilization on Yield attributes, Grain yield, Net returns and B:C ratio in sesame

\begin{tabular}{|c|c|c|c|c|c|c|}
\hline \multirow[t]{2}{*}{ Treatments } & \multicolumn{3}{|c|}{ Yield attributes } & \multirow[t]{2}{*}{$\begin{array}{c}\text { Grain yield } \\
(\mathrm{kg} / \mathrm{ha})\end{array}$} & \multirow[t]{2}{*}{$\begin{array}{c}\text { Net returns } \\
\text { (₹/ha) }\end{array}$} & \multirow[t]{2}{*}{$\begin{array}{l}\text { B:C } \\
\text { ratio }\end{array}$} \\
\hline & $\begin{array}{c}\text { Number of capsules } \\
\text { /plant }\end{array}$ & $\begin{array}{c}\text { Number of seeds } \\
\text { /capsule }\end{array}$ & $\begin{array}{l}\text { Test weight } \\
\text { (g) }\end{array}$ & & & \\
\hline Sulphur levels $(\mathrm{kg} / \mathrm{ha})$ & & & & & & \\
\hline Control & 18.86 & 30.83 & 2.11 & 519 & 24598 & 1.11 \\
\hline 15 & 29.13 & 43.19 & 2.35 & 647 & 35938 & 1.59 \\
\hline
\end{tabular}




\begin{tabular}{|c|c|c|c|c|c|c|}
\hline 30 & 34.46 & 51.09 & 2.55 & 712 & 41563 & 1.83 \\
\hline 45 & 35.08 & 52.68 & 2.66 & 723 & 42350 & 1.84 \\
\hline $\mathrm{SEm} \pm$ & 0.63 & 1.34 & 0.06 & 18 & 1297 & 0.06 \\
\hline $\mathrm{CD}(\mathrm{P}=0.05)$ & 1.81 & 3.87 & 0.18 & 53 & 3745 & 0.17 \\
\hline \multicolumn{7}{|c|}{ Zinc levels (kg zinc sulphate/ha) } \\
\hline Control & 19.48 & 30.24 & 2.07 & 489 & 23750 & 1.17 \\
\hline 10 & 28.85 & 43.20 & 2.41 & 638 & 35708 & 1.64 \\
\hline 20 & 33.85 & 51.77 & 2.55 & 725 & 42153 & 1.82 \\
\hline 30 & 35.35 & 52.58 & 2.65 & 749 & 42838 & 1.74 \\
\hline $\mathrm{SEm} \pm$ & 0.63 & 1.34 & 0.06 & 18 & 1297 & 0.06 \\
\hline $\mathrm{CD}(\mathrm{P}=0.05)$ & 1.81 & 3.87 & 0.18 & 53 & 3745 & 0.17 \\
\hline Interaction & 7.45 & 10.43 & 9.04 & 10 & Sig. & Sig. \\
\hline
\end{tabular}

Table 2: Interactive effect of sulphur and zinc fertilization on Grain Yield ( $\mathrm{kg} / \mathrm{ha})$, Net returns (₹/ha) and B:C ratio in sesame

\begin{tabular}{|c|c|c|c|c|c|c|c|c|c|c|c|c|c|c|c|}
\hline & \multicolumn{5}{|c|}{ Grain Yield } & \multicolumn{5}{|c|}{ Net Returns } & \multicolumn{5}{|c|}{ B:C ratio } \\
\hline Treatments & Zno & $\mathbf{Z n}_{10}$ & $\mathbf{Z n} 20$ & Zn30 & Mean & Zno & $\mathbf{Z n}_{10}$ & Zn20 & Zn30 & Mean & Zno & $\mathbf{Z n}_{10}$ & $\mathbf{Z n}_{20}$ & $\mathbf{Z n}_{30}$ & Mean \\
\hline $\mathrm{S}_{0}$ & 465 & 470 & 510 & 511 & 489 & 21860 & 22130 & 25550 & 25460 & 23750 & 1.09 & 1.10 & 1.26 & 1.24 & 1.17 \\
\hline S15 & 517 & 640 & 724 & 670 & 638 & 25110 & 36000 & 43380 & 38340 & 35708 & 1.17 & 1.67 & 1.99 & 1.75 & 1.64 \\
\hline S30 & 539 & 711 & 802 & 849 & 725 & 25660 & 40960 & 48970 & 53020 & 42153 & 1.12 & 1.78 & 2.11 & 2.27 & 1.82 \\
\hline S45 & 556 & 768 & 811 & 860 & 749 & 25760 & 44660 & 48350 & 52580 & 42838 & 1.06 & 1.83 & 1.96 & 2.12 & 1.74 \\
\hline Mean & 519 & 647 & 712 & 723 & & 24598 & 35938 & 41563 & 42350 & & 1.11 & 1.59 & 1.83 & 1.84 & \\
\hline SEm \pm & 36 & & & & & 2593 & & & & & 0.12 & & & & \\
\hline $\mathrm{CD}(\mathrm{P}=0.05)$ & 105 & & & & & 7489 & & & & & 0.34 & & & & \\
\hline
\end{tabular}

Table 3: Seed yield ( $Y$ ) as a function of sulphur and zinc fertilization $\left(Y=b_{0}+b_{1} X+b_{2} X^{2}\right)$

\begin{tabular}{|c|c|c|}
\hline Study parameters & Sulphur & Zinc \\
\hline 1. Partial regression coefficients & & \\
\hline b0 & 519.7375 & 488.8625 \\
\hline b1 & $10.3575^{* *}$ & $18.06125^{* *}$ \\
\hline b2 & -0.13028 & -0.31313 \\
\hline 2. Coefficients of & 153.93 & 159.11 \\
\hline (i) Determinations (R2) & $0.9999^{* *}$ & $0.9995^{* *}$ \\
\hline (ii) Multiple correlation (R) & $0.9998^{* *}$ & $0.9991^{* *}$ \\
\hline 3. Optimum level (kg/ha) & 39.24 & 26.30 \\
\hline 4. Yield at optimum level (kg/ha) & 725.57 & 747.29 \\
\hline 5. Response of optimum level (kg/ha) & 205.83 & 258.42 \\
\hline 6. Response/ kg S at optimum level (kg/ kg) & 5.24 & 9.8 \\
\hline 7. Response per kg S at S30 level & 6.45 & 11.8 \\
\hline
\end{tabular}

Note: The yield, $\mathrm{S}$ and $\mathrm{Zn}$ levels, responses and intercepts are given in $\mathrm{kg} / \mathrm{ha}$

** Significant at $1 \%$ level of significance

\section{Conclusion}

On the basis of the findings of the present investigation, it can be concluded that soil application of sulphur at $30 \mathrm{~kg} / \mathrm{ha}$ combined with $20 \mathrm{~kg}$ zinc sulphate/ha was found the most superior treatment combination for obtaining higher seed yield and net return in sesame, whereas, optimum dose of sulphur and zinc for sesame crop were computed as $39.23 \mathrm{~kg}$ $\mathrm{S} \mathrm{ha}^{-1}$ and $26.30 \mathrm{~kg} \mathrm{Zn} \mathrm{ha-}^{1}$, respectively.

\section{Acknowledgement}

The authors are thankful to Head, Department of Agronomy, S.K.N. College of Agriculture, Jobner for providing field staff, facilities and assistance in conducting this research.

\section{References}

1. Alloway BJ. Zinc in soils and crop nutrition. Second edition. IZA and IFA Brussels Belgium and Paris, France, 2008, 135.

2. Anonymous. Directorate of Economics and Statistics, Department of Agriculture and Cooperation, 201617, 161-166.

3. Bhosale ND, Dabhi BM, Gaikwad VP, Agarwal MC. Influence of potash and sulphur levels on yield, quality and economics of sesamum (Sesamum indicum L.).
International Journal of Plant Sciences. 2011; 6(2):335337.

4. Dash AK, Nayak BR, Panigraphy N, Mohapatra S, Samant PK. Performance of groundnut (Arachis hypogaea) under different levels of sulphur and irrigation. Indian Journal of Agronomy. 2013; 58(4):578582.

5. El Naim AM, El Dey EM, Jabereldar AA, Ahmed SE, Ahmed AA. Determination of suitable variety and seed rate of sesame (Sesamum indicum L.) in sandy dunes of Kordofan, Sudan. International Journal of Agriculture and Forestry. 2012; 2(4):175-179.

6. Miah MAM, Afroz A, Rashid MA, Shiblee SAM. Factors affecting adoption of improved sesame technologies in some selected areas in Bangladesh. The Agriculturists. 2015; 13(1):140-151.

7. Najar GR, Singh SR, Akhtar F, Hakim SA. Influence of S level on yield, uptake and quality of soybean (Glycine max) under temperate conditions of Kashmir valley. Indian Journal of Agricultural Science. 2011; 81:25-45.

8. Pathan ARK, Nag AK. Influence of phosphorus and sulphur on yield and nutrient content of taramira. Annals of Experimental Agriculture \& Allied Science. 2008; 3:69-72. 
9. Prasad R. Textbook of Field Crop Production Commercial Crops. Indian Council of Agricultural Research New Delhi. 2017; II(2):200.

10. Singh MV. Scenario of zinc deficiency in Indian soils and its influence on zinc enrichment in crops for improving human and animal health. (In): $3^{\text {rd }}$ International Zinc Symposium: Improving Crop Production and Human Health, Hyderabad, India, 2011, 10-14.

11. Shah MA, Munaf A, Hussain M, Farooq S, Zafar-ul-Hya M. Sulphur fertilization improves the sesame productivity and economic return under rainfed condition. International Journal of Agriculture and Biology. 2013; 15:1301-1306.

12. Shinde SD, Raskar BS, Tamboli BD. Effect of spacing and sulphur levels on productivity of sesame (Sesamum indicum L.) under summer condition. Journal of Maharastra Agriculture University. 2011; 36(1):28-31.

13. Singaravel R, Imayavaramban $Y$, Dhanunathan $\mathrm{K}$, Shanumughapriya N. Response of sesame (Sesamum indicum L.) to manganese and zinc nutrition. Journal of Oilseeds Research. 2001; 18:136-138.

14. Tripathi ML, Rajput RL. Response of sesame (Sesamum indicum L.) genotypes to levels of fertilizers. Advances in Plant Sciences. 2007; 20(2):521-522.

15. Vaghani JJ, Polara KB, Chovatia PK, Thumar BV, Parmar KB. Effect of nitrogen, potassium and sulphur on their content and uptake by sesame. An Asian Journal of Soil Science. 2010; 5:356-358.

16. Yadav SB, Adibi Singh RP, Singh A. Response of sulphur nutrition on nutritional characteristics of oil and cake of sesame (Sesamum indicum L.) Varieties. Journal of Oilseeds Research. 2008; 25(1):38-40. 